\title{
Musical editions for the Protestant churches of Strasbourg until the end of the Interim (1555)
}

Beat Föllmi

\section{Preliminary remarks}

In the first decades of the Reformation, the free imperial city of Strasbourg was the most important centre in the production of printed music for the emerging Evangelical churches. The number of editions printed there far exceeds all other places in Germany, such as Wittenberg, Augsburg, Leipzig, Magdeburg, Nuremberg and Erfurt. Only in the second half of the century did the production of hymnbooks in Strasbourg decline, and production shift to other cities. This is associated with the politically difficult situation of Strasbourg following the 1547/1548 Diet of Augsburg, when Catholic worship was forcibly readmitted in Strasbourg for several years.

The most common type of printed book containing sacred music published at Strasbourg was the hymnbook, intended either for liturgical or personal use. Several of these were obviously intended for use in worship by the new Protestant churches in Strasbourg; others were produced for private use, within the city or beyond. In any case, the Strasbourg hymnbooks, with one exception to which we will return, were not official 'church hymnbooks' authorised by the clergy. The role played by publishing, technical and pragmatic questions in the design of hymnbooks has not yet been fully explored.

In this chapter we will examine this corpus of printed sacred music from Strasbourg with regard to various aspects: contents, repertoire, paratexts such as prefaces, notation, printing technique, mise-en-page, decoration and target audience. We will be guided by the question of the necessary conditions for the production of hymnbooks at Strasbourg in the early days of the Reformation.

Previous research has established that most of the first Protestant hymnbooks were not initiated directly by the Reformers. One exception is the Geneva Psalter. For more than twenty years following his return to Geneva in 1541, Jean Calvin worked towards the publication of the translation of the complete Psalter in verse. The corresponding titles of the Geneva Psalter editions up to 1562, that is, Fifty Psalms in French (Cinquante Pseaumes en françois) or Eighty-three Psalms by David (Octante trois Pseaumes de David), show their provisional character as well as the goal, which was clearly defined from the beginning: that all 150 biblical psalms should be completely provided with melodies for use in worship. ${ }^{1}$

What Daniel Trocmé-Latter wrote in his study on the first Strasbourg liturgies, namely, that '[they] were not commissioned by the reformers but were more likely to have been attempts by opportunistic publishers to profit from the uncertain situation and lack of any official decree on the matter', applies similarly to almost all the hymnbooks printed in the city. ${ }^{2}$ These books were produced and distributed on the initiative of the printers, albeit 
usually in consultation with the preachers. Martin Bucer, the Reformer of Strasbourg, first set out the foundations of singing within the new worship service in his reformatory declaration Ground and Reason (1525). ${ }^{3}$ But it can hardly be assumed that all Strasbourg hymnbooks followed these guidelines from this moment on.

\section{The Corpus}

The numerous editions of the hymnbooks in Strasbourg in the sixteenth century are well known. ${ }^{4}$ Any open questions are likely to concern multiple issues and pamphlets of only a few pages. Besides 'natural enemies' in Strasbourg, the devastating fire in the library during the siege and bombing of the city in the Franco-Prussian War of 1870 was responsible for the probably definitive loss of some editions.

From the beginning of the Reformation until the end of the Interim shortly after the middle of the century, that is, a period of thirty years, about fifty editions containing sacred songs are known. ${ }^{5}$ Almost half were printed between 1524 and 1527. After this time, the frequency decreases significantly. After 1547, no German hymnbooks appeared until after the Interim. During the Interim, two French Psalters were printed. The next hymnbook printed in Strasbourg was All the Psalms, hymns and spiritual songs (Alle Psalmen/ Hymni) vnnd Geystliche Lieder), published by Paul and Philipp Köpfel in $1557 .{ }^{6}$ In other words, not a single German hymnbook was printed in Strasbourg during the Interim, a period of almost ten years.

The production of hymnbooks during these three decades can be divided into three phases. The first years of the Reformation, until the middle of the 1530s, represented a period of experimentation. The Catholic services, both the Mass and the Liturgy of the Hours, continued to exist at first (albeit limited to a few churches), but were increasingly suppressed. The Mass was only officially abolished in 1529 by a decision of the city's justices (Schöffen). This first phase saw the production of single editions containing one or a few songs: the German Credo (1525), ${ }^{7}$ Matthias Greiter's version of Psalm 51 (1525), ${ }^{8}$ Es ist die Wahrheit bracht an Tag (1527), ${ }^{9}$ the German Te Deum by Johannes Brenz together with a translation of Psalm 46 by Johannes Frosch (1529), ${ }^{10}$ as well as several editions with just a few psalms each, all printed in $1527 .{ }^{11}$

The abolition of the Mass marks the beginning of a second phase of consolidation, which came to an end in the late 1530s. During this period, fewer songbooks were printed, but a large corpus of the Psalms and canticles was created. ${ }^{12}$ The first part of the 'Strasbourg Psalter', with probably 131 songs, most of them with notes, was printed in 1537, apparently simultaneously in two different editions with identical titles: Psalms and spiritual songs. ${ }^{13}$ The first edition was printed by Wolfgang Köpfel in octavo, while another octavo edition (with slightly larger pages) was printed for Köpfel by Johannes Prüss the Younger. Probably in the following year, 1538, Köpfel reprinted the same hymnbook. ${ }^{14}$ In 1541 he commissioned Georg Messerschmid to reprint the book on his behalf. ${ }^{15}$ In 1543, Köpfel reprinted the book again, apparently for the last time. ${ }^{16}$

The second section of the Psalter contains 148 texts, most of which are supplied with notes. This was intended as a supplement to the first section, since it contains no duplicates. The title betrays the claim to present a complete rhymed Psalter: Psalter, that is, all the Psalms of David, with their melodies, together with many beautiful Christian songs (Psalter. Das seindt alle Psalmen Dauids/ mit jren Melodeien sampt vil Schönen Christlichen liedern). ${ }^{17}$ 
A reprint of this edition (with melodies) appeared in $1544 .{ }^{18}$ Thus a normative repertoire of about 220 songs (psalms and biblical canticles) was available. However, it was only in use in the Protestant service for a short time.

In the final phase, which lasted until the Interim, which began with Bucer's forced exile in 1549, a change in repertoire is already discernible. The Gesangbuich of 1541 contains only sixty-six songs, which - as the title page notes - were 'collected from the hymnbooks of the Wittenberg, Strasbourg, and other churches' ${ }^{19}$ The two editions of A new and select songbook (Ein New Auserlesen Gesangbüchlin, 1545 and 1547) also contain mostly songs of the Wittenberg Reformation, especially those by Luther. ${ }^{20}$

A turning point in the production of hymnbooks in Strasbourg coincides with the defeat of the Protestants by Emperor Charles V in the Battle of Mühlberg (1547). From this year, no more German hymnbooks were printed in Strasbourg until after the end of the Interim. Only two different editions of the French rhyming Psalter (still incomplete) appeared in 1548 and 1553. Hymnbook production recommenced in Strasbourg only after the end of the Interim, with the Peace of Augsburg in 1555, and the abdication of Charles V in 1556. From this time until the end of the sixteenth century, forty-five hymnbooks were printed. The titles clearly show the new, orthodox Lutheran confessional orientation under Johannes Marbach: Luther's name is often mentioned explicitly, for example, on the numerous editions of Psalms, Spiritual Songs and Canticles (Psalmen, Geystliche Lieder und Lobgesänge). ${ }^{21}$

Apart from hymnbooks containing the repertoire of the 'official' church of Strasbourg, two other repertoires were printed in the city during our period. Between 1534 and 1536, Katharina Zell, the wife of the Münster preacher Matthäus Zell, commissioned the printing of an extensive hymnbook in four sections, which contained the songs of the Bohemian Brethren: Of Jesus Christ our Saviour (Von Christo Jesu vnserem såligmacher). This four-part work was published by Jakob Frölich. ${ }^{22}$ This was a courageous step at a moment when a Strasbourg synod decided to take tougher measures against dissidents. The four booklets were not intended for worship, but for private piety. In the preface, addressed to laypeople, especially housewives, Katharina Zell describes the origin of the publication: she had received the hymnbook of the Bohemian Brethren, but she did not know the author, Michel Weiße, personally. The aim of her hymnbook was to replace the rejected songs in circulation with catechetical songs in which one might simultaneously learn about the life of Jesus. These hymns were suitable for regular days, special days in the Christian calendar, and various crucial moments during the believer's life. She explains that she divided 158 songs from Weiße's extensive hymnal into four parts, which were to be sold at a low price ('ij. iij. vnd iiij. pfenning'). She names the target audience precisely: the simple folk, the craftsmen, the peasants, the maidservants, the housewives, who would, she hoped, sing spiritual songs in their daily tasks. ${ }^{23}$ The songs are accompanied by notated melodies.

A French repertoire was also printed in Strasbourg during the period under study. In 1539, less than a year after his arrival in the city, Jean Calvin commissioned Johannes Knobloch the Younger to print a simple but carefully produced booklet, without preface or liturgical order. ${ }^{24}$ It contains twenty-two songs - nineteen psalms, the Nunc dimittis, the Decalogue and the Credo - all with melodies. It would take a little more than twenty years for this inconspicuous booklet to become the complete Geneva Psalter, with its impressive history. After Calvin's departure, two extended reprints of this French psalm repertoire appeared at Strasbourg until the Interim, in 1542 and 1545. 


\section{The printers}

Music had been printed at Strasbourg since the 1470s. In the period studied, that is, between 1524 and 1555, a total of twenty-five workshops in the city printed music. However, only a handful were active in printing German hymnbooks.

The most important Strasbourg music printer in the first half of the sixteenth century was Peter Schöffer the Younger (c. 1475/1480-1547), who came to Strasbourg from Mainz or Worms in 1529. ${ }^{25}$ Bucer and Capito helped him set up his workshop. Since 1533 he had worked together with Mathias Biener, called Apiarius (1495/1500-1554), who came from Basel, where he had learnt the printing trade, to Strasbourg. The special technical feature of the workshop of Schöffer and Apiarius is that, for the first time in Strasbourg, these partners printed music not from woodblocks, but in type, using the technique pioneered by Petrucci for mensural music. Their most important publication is the collection of the Sixty-five German songs (Fünff ond sechzig teütscher Lieder), published in 1536 in five partbooks. ${ }^{26}$ It contains up-to-date pieces, mainly by composers who were still alive or had died only recently. It is therefore not surprising that the only polyphonic sacred music with German text that appeared in Strasbourg between the beginning of the Reformation and the Interim was printed by Schöffer and Apiarius, namely Johann Walter's Gesangbuch, which was imported from Wittenberg. ${ }^{27}$

The most important printer of hymnbooks in Strasbourg in the first half of the sixteenth century was Wolfgang Köpfel, who had a monopoly in this area. Köpfel was born in Hagenau and came from Basel to Strasbourg in 1522, where he was active until his death in 1554. He benefited from the support, including financial backing, of his uncle, the Strasbourg Reformer Wolfgang Capito (a Latinised form of 'Köpfel'). ${ }^{28}$ Thus Köpfel became the most important printer of the Strasbourg Reformation, publishing writings by Luther, Bucer, Capito and Zell. ${ }^{29} \mathrm{Up}$ to the Interim, almost all liturgical books and hymnbooks for the German-speaking church of Strasbourg originated from Köpfel's workshop. His only competition came in the first years of the Reformation, from Johannes Knobloch the Elder, who printed musical broadsheets, such as the German Credo, in 1524/1525. ${ }^{30}$ In 1527 Johannes Prüss the Younger published a polemic on the Last Supper controversy, which also contained a song with notes. ${ }^{31}$ Songs with notes are also contained in the Order of the Lord's Supper, which Johannes Schwan published in two editions in 1525 (see Figure 3.1). ${ }^{32}$

For more extensive editions, Köpfel also worked with other printers as a publisher. He commissioned others to print the first part of the Psalter: two editions by Johannes Prüss the Younger in 1538; ${ }^{33}$ another by Georg Messerschmid 1538 or 1539; and a final edition in 1541, again by Messerschmid. ${ }^{34}$ The latter (also known as Waldmüller) ${ }^{35}$ also produced the most magnificent of all musical editions printed at Strasbourg in the sixteenth century, the Gesangbich of $1541 .{ }^{36}$ Surprisingly, the name of the printer is not mentioned on the title page of the first edition; it appears only in the next edition (1560). ${ }^{37}$ But Martin Bucer mentions him in his preface: 'the honourable printer Jörg Waldmüller, called Messerschmid, acceded to requests and commands to print a songbook for the good of the dear church, and to promote pious singing in Christian congregations, schools and places of instruction, with considerable expense and effort and with great diligence, as the book itself attests, so that the psalms and spiritual songs included in it might be issued in the neatest and most carefully corrected edition possible' ${ }^{38}$

Messerschmid printed from 1541 to 1560 in the workshop of Johannes Knobloch the Younger, from whose father he had probably learnt his trade. Later, at an unknown time, the Knobloch workshop seems to have passed into Messerschmid's possession. ${ }^{39}$ It is 


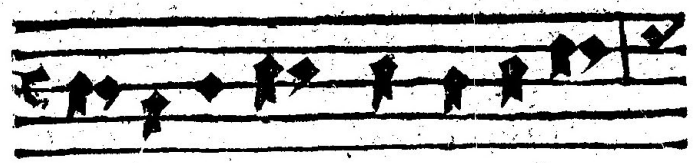

2uf thieffer not forey ids sitir/ Orin gneotg ozen fer "3ü mir/

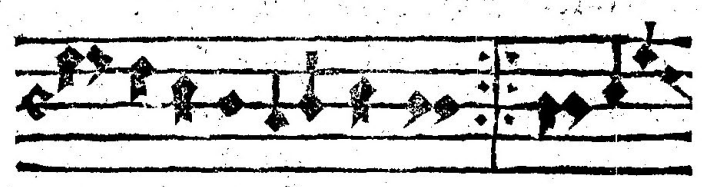

\section{Berzgott erhơz meint rúffen: Oañ foda onno meinet bitt fye offen.}

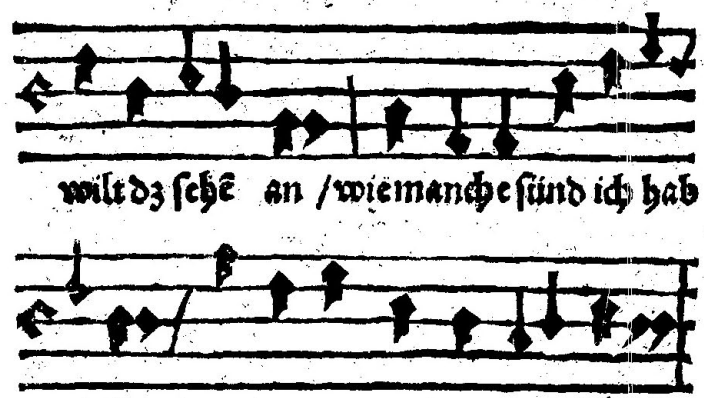

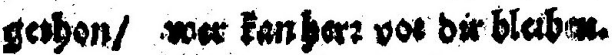

Figure 3.1 Ordnung des Herren Nachtmal (Strasbourg: Johann Schwan, 1525), vdm 247, fol. A7 ${ }^{\mathrm{r}}$. Source: Munich, Bayerische Staatsbibliothek, Rar. 4114\#Beibd.4.

surprising that this magnificent work of the Protestant church of Strasbourg was not entrusted to the 'house printer' Köpfel. Either Köpfel did not have the necessary expertise to carry out multiple-impression printing, or he did not want to take the risk of publishing such a work, with its attendant costs. Bucer's formulation 'with not inconsiderable expense and effort' ('nicht mit geringem kosten vnd mùh') in the preface points in this direction.

The psalm collections for the French-speaking exile community in Strasbourg were first published by local printers. In 1539, Calvin's Aulcuns pseaulmes et cantiques mys en chant was published by Johannes Knobloch the Younger, who took over his father's workshop after his death in 1538. ${ }^{40}$ In 1542 appeared Pierre Brully's 'pseudo-Romanus' (so called because of the fictitious printing address of Rome), both collections containing French psalm songs. ${ }^{41}$ The lost successor of the pseudo-Romanus, La forme des prieres et chantz ecclesiastiques, was probably published by Messerschmid in the Knobloch workshop in $1545 .{ }^{42}$ However, printers exiled from France were also active in Strasbourg. The printer François Perrin worked together with the bookseller Pierre Estiart. The two were in close contact with the centres of the French book trade, Geneva and Lyons, but also with Basel, and in the 1550s supplied France and the Netherlands with the writings of Rhenish and Swiss theologians. Less important on a European level, even if musically important, was the printer 
Rémy Guédon, who printed the Pseaumes de David traduictz en rithme françoise in Strasbourg in $1548 .{ }^{43}$ Finally, in 1553, Wolfgang Köpfel published the Pseaumes de David, mis en rime Francoyse, the last French psalm collection. ${ }^{44}$

\section{Prefaces}

Practically all Strasbourg hymnbooks of the period studied contain a preface. Broadsheets and pamphlets, which contain only one or a few songs, are the exception to this tendency. Apart from titles with purely Lutheran repertoire, which can be described as imported products' and which contain a foreword by Luther, almost all prefaces to the Germanlanguage Strasbourg hymnbooks come from the respective printer, who was in most cases Wolfgang Köpfel. ${ }^{45}$ It is unusual that the Strasbourg reformers did not write forewords, since Luther had recognised from the beginning the importance of the foreword as a propagandistic and catechetical instrument in the service of the Reformation. From the review of the prefaces it can be seen that the printers acted on their own initiative, even if in accordance with the will of the preachers.

The first edition of the Teutsch kirchen ampt (1524) does not yet include a foreword. ${ }^{46}$ The next edition, printed the same year, is accompanied by a short preface without any indication of the author; however, the text reveals that the author was the printer Wolfgang Köpfel. ${ }^{47} \mathrm{He}$ writes in the first person, in the name of the 'servants of the Word', that is, of the preachers. He explains that these have introduced new songs: 'For this reason I have printed them besides other prayers' ('Deßhalb habe ich sye neben anderen gebetten getruckt'). ${ }^{48}$

In the detailed foreword to the Psalms, Prayers and Church Order of 1530, the full name of the printer is given as follows: 'Wolfgang Köpfel, printer at Strasbourg' ('Wolfgang Ko̊pfel Buch trucker zů Straßburg'). ${ }^{49}$ His remarks show that he personally selected the forty-six songs in the hymnbook, and even reveal his criteria. On one hand he limited the selection so that the congregation would not be overwhelmed by songs. On the other, he largely renounced 'spiritual songs by estimable and spirited authors' ('geystliche lieder von achtbaren vnd geystreichen'), since the congregation could easily be blinded by the famous names. In concrete terms this means that no song by Luther or the other Wittenberg poets appears in the hymnbook. Was Köpfel responsible for this, or was he acted on the instructions of Bucer and the preachers?

When Köpfel published the second part of the Psalter in 1538 (see Figure 3.2), ${ }^{50}$ which presented a total of 189 Psalms and twenty-six canticles, the printer announced his publishing project in the preface ('Wolff Kòpfel zum Leser'):

Dear reader, until now I have printed the Psalms and spiritual songs, as they are sung here and there in Christian congregations, piecemeal, as I have been able to get my hands on them. However, now that the complete German translation of the whole Psalter has recently been brought to completion through the great diligence of many famous, distinguished poets, I have printed it along with the previous church orders and spiritual songs in a single volume. ${ }^{51}$

Johannes Schwan, a former Franciscan from Marburg who had joined the Reformation and came to Strasbourg, also appears in his own name in the foreword to his Order of the Lord's Supper (1525) ${ }^{52}$ : 'I, Johannes Schwan, citizen of Strasbourg' ('ich, Johannes Schwan, burger zů Straßburg').$^{53}$ He made it clear that he acted in harmony with the preachers: 'And since they (the servants of the Word) are not hesitant to carry this out, since they are preaching the Word of God, I have printed this current [liturgical] use' ('Und so nưn sy 


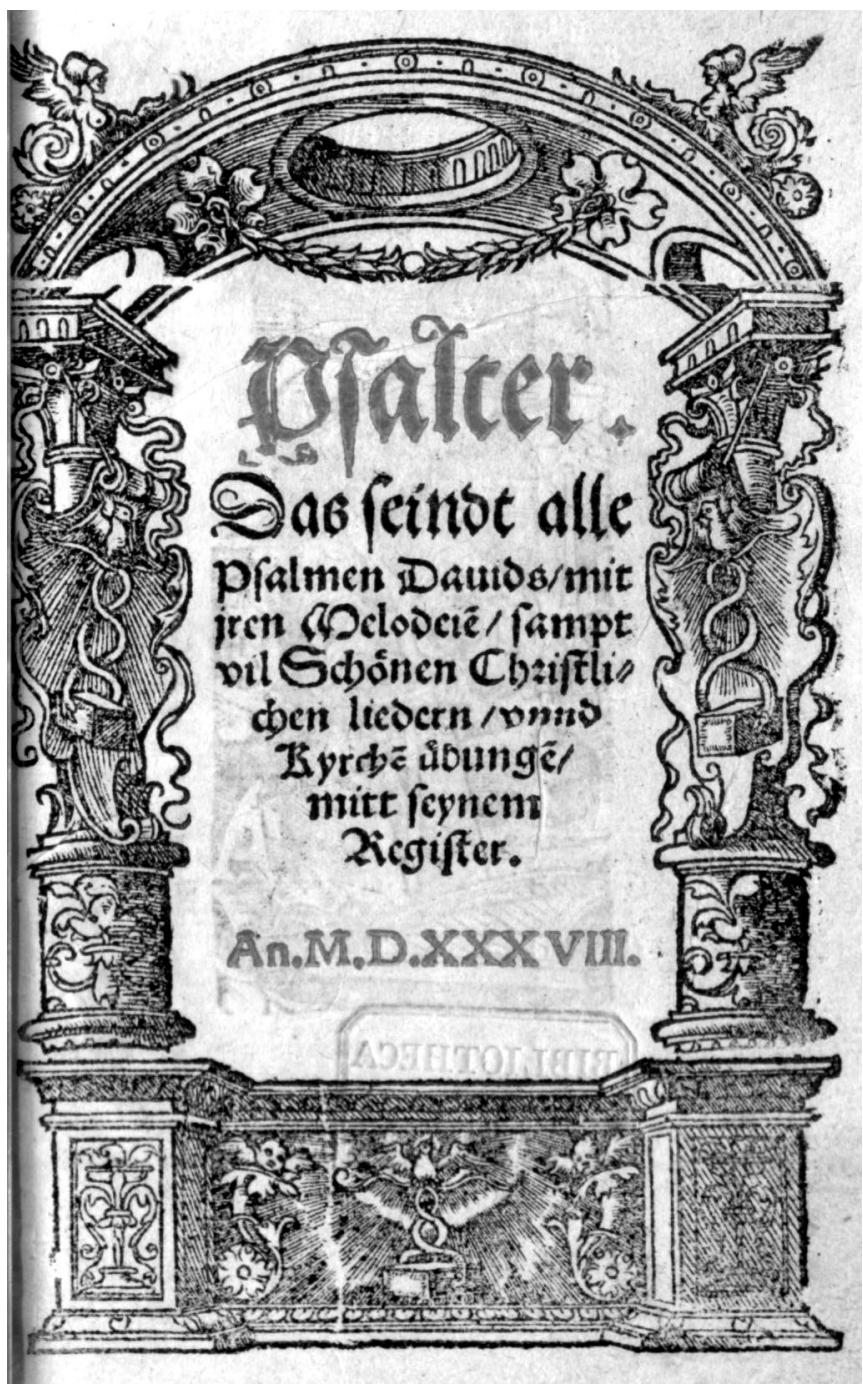

Figure 3.2 Psalter: das seindt alle Psalmen Davids (Strasbourg: Wolfgang Köpfel, 1538), vdm 457, fol. $[\alpha] 1^{\mathrm{r}}$.

Source: Munich, Bayerische Staatsbibliothek, Res/Liturg. 1128.

(die diener des worts) des thůn nit scheuch tragen, die weyl sye das wort gottes handlen, hab ich disem yetzigen brauch [...] in truck geordnet' $)^{54}$

The Reformer Martin Bucer wrote a foreword to only one printed collection of songs: the great Gesangbich, which Georg Messerschmid printed in 1541. The title refers to a change in repertoire: Song book, in which all the most distinguished and best Psalms, spiritual songs and chant melodies, gathered from the song books of Wittenberg, Strasbourg and other churches, corrected and printed with particular care (Gesangbuch, darinn begriffen sind, die aller furnemisten ond besten Psalmen/Geistliche Lieder/ ond Chorgeseng/aus dem Wittembergischen/Strasburgischen/ ond anderer Kirchen Gesangbüchlin züsamen bracht/ ond mit besonderem fleis corrigiert vnd gedrucket). ${ }^{55}$ The previous psalm repertoire, which was apparently distributed in numerous editions through Köpfel's efforts, was pushed back and replaced by a Lutheran repertoire 
widespread throughout Protestant Germany. The paradigm shift is also supported by the fact that in the Gesangbuch, for the first time, the authors of each some are named systematically in the title of each song. This Gesangbuch is also the first example of the genre of the Cantional in Strasbourg.

Bucer's extensive preface is the only preface to a hymnbook written by a Strasbourg reformer until the Interim, apart from reprints of Luther's prefaces. It is a verbose apology and justification of church song, a theological statement that refers explicitly to Luther in several places. In his preface, Bucer worries above all about correct singing, that is, that 'very beautiful and spiritual songs' ('recht artige vnd geistliche Lieder') are sung and nothing 'unspiritual and incorrigible' was 'mixed in' ('ongeistlichs vnd onbesserlichs eingemischet'). Bucer's preface was reprinted in the following (extended) editions (1545 and 1547, as well as after the Interim). ${ }^{56}$ However, these editions are attributed simply to a 'Servant of the Word to the Churches at Strasbourg' ('Diener des Worts der Kirchen zů Strasburg'). (In the meantime Bucer had fallen out of favour and went into exile in England.) The preface also contains some changes. According to the preface, the hymnal, which was now greatly reduced in size (to octavo format), was supposed to be inexpensive so that young and old might buy and use it.

The French-language hymnbooks were supplied with prefaces only after Calvin's departure from Strasbourg in September 1541. The aforementioned 'pseudo-Romanus', which Johannes Prüss the Younger printed in 1542, contains a short French foreword addressed 'To the Christian reader' ('Au Lecteur Crestien'), which legitimises psalm singing in a conventional way. The anonymous author could be Calvin (or someone who excerpted Calvin's preface) because the content is similar to that of the edition of the Geneva Psalter printed the same year. ${ }^{57}$ The preface was obviously reprinted again in the Strasbourg edition of $1545 .{ }^{58}$ We cannot say anything more exact, since no copy of this edition is preserved.

\section{Printing technique}

The Strasbourg printers Johannes Schwan, Wolfgang Köpfel and Jakob Frölich printed the musical notation in their hymnbooks from woodblocks until the mid-1540s. The somewhat clumsy Hufnagel notation was well served by this printing technique. The printer clearly used the same wooden blocks for multiple editions over several years. Each staff was produced on a single block and could thus be placed at different points on the page. However, some degradation would occur, and a comparison between Köpfel's two editions of Psalms, prayers and church order (Psalmen gebett und Kirchenübung) from 1526 and 1530 shows that thin lines such as dividing lines have often broken in the later edition. ${ }^{59}$

The quality of Strasbourg editions printed with woodblocks is satisfactory, but not excellent. Woodcut technology could not be used for large print runs. However, the manufacturing costs may have been relatively low, as Katharina Zell mentions in her foreword. Johann Knobloch the Younger produced high-quality woodcuts for the printing of Calvin's Aulcuns pseaulmes et cantiques mys en chant (1539). ${ }^{60}$ Here the printer used mensural notation, not the Hufnagel notation customary for liturgical repertoire in Latin or German in books produced in the German cultural area, including Strasbourg. Knobloch printed this French psalm repertoire again in 1545 (with some additions), but since no copy has survived, nothing can be said about the printing technique. ${ }^{61}$ Rémy Guédon's edition of French psalms (1548) also used mensural notation in block printing, again of a high quality. ${ }^{62}$ Finally, in 1553 Köpfel reprinted the French psalm repertoire, once again using woodblock printing. ${ }^{63}$ 
It is noticeable that all French-language Strasbourg hymnbooks were printed in mensural notation. The fact that the Strasbourg printers Knobloch, Prüss and Köpfel did not use Hufnagel for the French hymnbooks is due to the target audience, which consisted of French and Flemish exiles. Moreover, these editions were also to be sold beyond Strasbourg, especially in Lorraine.

Polyphonic music in mensural notation, such as the two editions of the Wittenbergisches Gesangbüchlein (1534 and 1537), which was printed in partbooks using a multipleimpression technique, perfected by the workshop of Peter Schöffer and Matthias Apiarius in Strasbourg. ${ }^{64}$ In 1545 the technique was used for the first time at Strasbourg to print hymnbooks, and from then on replaced woodblock printing. In 1545 and 1547 Wolfgang Köpfel printed two editions of the Lutheran vocal repertoire in mensural notation by means of single-impression printing. ${ }^{65}$

An exception to the tendency towards single impression is the large Gesangbich of 1541, which Georg Messerschmid produced in multiple-impression printing; indeed, the book was produced elaborately in every respect: the staves were first printed in red, and the notes - in Hufnagel notation - in black.

\section{Decoration and mise-en-page}

The Strasbourg hymnbooks from the period under investigation are generally small, in octavo or quarto format. The format and the woodblock printing used kept the production costs relatively low. The selling price obviously played a role in the decoration, because these books usually have no other decoration apart from the title page. The practice of providing each section of the hymnbook with a suitable picture only emerged after the Interim.

The title pages of the early Strasbourg hymnbooks mostly have simple ornamental borders on the four sides, as familiar from Wittenberg hymnbooks. The woodcuts were often used for several editions, even for different works. Thus Köpfel used the same title strips for Ordenung und ynnhalt Teütscher Mess und Vesper (1524/1525) and the Enchiridion geistlicher Gesänge (with fictitious place of printing). ${ }^{66}$ Köpfel later used the same illustrations for at least six subsequent editions of Psalmen gebett und Kirchenübung (between 1526 and 1536), thus creating a graphic unity through the recognition effect. ${ }^{67}$ The Psalter of 1538 deviates from this scheme for the first time. Instead of four decorative borders around the outside, a uniform frame in the form of a classical Roman arch is used (see Figure 3.2). Köpfel dispenses with religious iconography, except, at most, the cornerstone (Psalm 118:22 or Matthew 21:42), which was in any case Köpfel's printer's mark. Several title pages of early hymnbooks show a profane pictorial language such as putti, mythical creatures, ancient vases or acanthus decoration. The title page of the German Credo, published as a pamphlet in 1524/1525 by Johannes Knobloch the Elder, even features a naked woman. ${ }^{68}$

Köpfel quickly established a characteristic composition of the title page, whose pictorial language was already programmatically religious in the earliest editions. The Teütsch kirchen ampt (1524), for example, shows two symbols of the evangelists in the upper register (the ox for Luke and the lion for Mark), while in the middle God the Father (with mitre) stretches out his hands. ${ }^{69}$ In the left register Jesus preaches the Sermon on the Mount in front of a crowd of people; above is the inscription 'Believe in the Good News' ('Gloubet dem Evangelio'). On the right we see Jesus' baptism in the Jordan. In the previous edition of the same year, in the lower register we see the two other evangelists: on the left an eagle for John, on the right a man for Matthew. ${ }^{70}$ In the following issue, however, a 
polemical image is inserted: in the middle, Jesus preaches before a crowd of people, among whom one can read 'the just man lives by faith' ('Der gerecht uß dem Glouben lebt', Romans 1:17, Galatians 3:11, Hebrews 10:38), a key verse in Luther's theology of justification, while on the left side, the Pope is imprisoned within the walls of Rome.

The great Gesangbich of 1541 also differs from all other Strasbourg hymnbooks from our period in terms of its mise-en-page. The large-format print is two-coloured throughout (red and black), the initials are elaborately executed, and the rubrics are adorned with decorative strips. A finely executed woodcut, probably designed by Hans Baldung Grien, is used on three occasions, at the beginning of new sections.

\section{The target audience}

The question about the target audience of the hymnbooks appears easy to answer, as hymnbooks seem to belong in the hands of worshippers. Ideological historiography of the nineteenth and twentieth centuries sees the hymnal as one of the most important media for the dissemination of the Reformation (and German culture). However, it is unclear whether the hymnbook was actually used in the sixteenth century during the divine service or for private piety. In the latter case, it may be assumed that a single copy per household was sufficient.

The entire congregation - men, women, children - sang in the church services of the Strasbourg churches probably as early as the mid-1520s, but this does not necessarily mean that hymnbooks were actually used in the service. We must consider two factors: the number of copies in circulation and the culture of reading and singing.

Since Köpfel was the only printer supplying the churches of Strasbourg with hymnbooks, it was impossible for him to produce enough copies to provide each parishioner with a hymnbook. At the beginning of the Reformation, Strasbourg had a population of around 20,000. Added to these were the inhabitants of the villages on either side of the Rhine, which were directly dependent on the city. Even if we count only adults, this would amount to at least 10,000 to 15,000 persons. It is obvious that such a great number of hymnbooks could not be achieved by woodblock printing.

Second, it cannot be assumed that the reading of text - and even more so, of music was generally widespread. If the hymnal had essentially been used only to read the text, why would printers have taken the trouble to produce woodcuts of the notes, which certainly made the production more expensive? The hymnbooks were thus aimed at a small group of humanistically educated citizens who had learnt to read music as part of their education, either at Latin schools or the arts faculty of a university. Music lessons were already on the curriculum of school at the Carmelite monastery under Otto Brunfels in the 1520s, and regular music lessons were prescribed at the Protestant school of Johannes Sturm, founded in $1538 .{ }^{71}$ However, only a small number of male pupils from the better urban milieus benefited from these lessons. The vast majority of worshippers learnt text and melody by listening to the precentor choir, which consisted of students from Sturm's school.

It is possible, however, that a change in practice was prompted by the rapidly growing repertoire - by the end of the 1530s there were well over 200 songs - and the influence of music lessons at school. Köpfel mentions in the New Auserlesen Gesangbüchlin (1545) that he numbered the verses, 'so that the people might the better find where and what they were to sing' ('daher die leut desto bas finden, wo vnd was man singet') ${ }^{72}$ This could suggest that at least some worshippers sang from a hymnbook during the worship service. 
With regard to the target audience, the great Gesangbich of 1541 constitutes an exception. Due to its elaborate production and its unusual format of about $33 \times 50 \mathrm{~cm}$, it was not intended for individuals, but for parishes and schools, where it was used to teach the choir, and during church services, when it was placed on a lectern. Its price must have been enormous, so that some smaller rural communities preferred to copy out the text and music by hand rather than purchase it. ${ }^{73}$

An indication of a target audience outside Strasbourg is given by the aforementioned 'pseudo-Romanus' of 1542. This edition of some French psalms was obviously not intended exclusively for the French and Flemish exile community at Strasbourg, because Johannes Prüss the Younger also supplied foreign places. To avoid the confiscation of his goods by Roman Catholic authorities, he printed the following fictitious colophon at the end of the booklet: 'Printed at Rome by the commandment of the pope, by Théodore Prüss, a German, his ordinary printer' ('Imprime a Rome par le commandement du Pape. par Theodore Brüß Allemant. son imprimeur ordinaire').${ }^{74}$ However, this bold assertion became his downfall. When he delivered 600 copies to the Protestant congregations in Metz in early 1542, the delivery was confiscated by the Metz authorities precisely because the hymnal allegedly contained 'papist' songs. Pierre Brully, Calvin's preacher and successor, sent a petition to the Strasbourg Council to intervene in favour of Prüss, the printer, to release the confiscated copies. The councillors of Metz did not allow themselves to be deceived by the colophon, which was made 'from the ill-advised and excessive zeal of the printer' ('aus onberathenem überigen vleis vom drucker hinbeigethon'). ${ }^{75}$ The council acceded to the request and on 25 March stated that its secretary should write that Prüss' book conformed to the ones printed and used at Metz ('sogleich und früntlich schriben, und sein hier getruckt undt den psalmbüchlin allhie gemess, schriben'). ${ }^{76}$ Obviously, the Strasbourg intervention was successful, because when one and a half years later in Metz 'heretical' books and writings were banned by imperial decree, there was explicit mention of 'Psalms in French with the melodies, which are commonly called "Marotines" [that is, named after Clément Marot], and other similar psalms or songs' ('Psaulmes en François avec les notes des chants qui s'appellent vulgairement Marotines et d'aultres semblables Pseaulmes ou chantz'). ${ }^{77}$

\section{Conclusion}

At the beginning of the Reformation, the initiative for printed liturgical books for the new church communities at Strasbourg clearly came from the printers. In this early period there was a great demand to be able to read about the innovations practised in the churches, as Köpfel hints in the foreword to the Strasbourg church order (1525). ${ }^{78}$ This also led to tensions between printers and preachers, as the printed church orders and chants did not necessarily correspond to custom. In that foreword, the printer Köpfel admitted that he had published the previous editions himself and without the consent of the preachers: 'against their will and agreement' ('wider jren willen und gehelle'). With the publication of Martin Bucer's Ground and Reason from the Holy Scripture for the novelties in the celebration of the Lord's Supper, commonly called the Mass (Grund und Ursach auß gotlicher Schrifft der Neuerungen an dem Nachtmal des Herren so man die Mess nennet, 1524), printed by Köpfel, the situation had changed: the preachers now recognised Bucer's principles for a kind of singing consonant with the Gospel, and he, Köpfel, would now present these improved songs: 'And if previously I may have inadvertently served the congregation and the preachers ill with my books, I hope to make good this fault with this better book' ('Und hiemit, wes ich zůuor auß vnwissen der gemeynn vnd den predicanten durch mein trucken mißdient 
haben mag, will ich, als ich hoff, mit dißem bessern trucken erstattet vnd widerlegt haben'). ${ }^{79}$ Bucer's Ground and Reason of 1524 did indeed represent the theological basis for innovations in the divine service and described the course of a communion service. But with regard to the selection of songs, nothing concrete can be found in the Bible, so it was not possible to use it as justification in the development of the rapidly growing repertoire. Wolfgang Köpfel now established himself, probably because of his relatives and his contacts, as the 'house printer' of the Strasbourg Reformation. Thus, until the constitution of a genuine Strasbourg repertoire at the end of the 1530s, he acted in consort with the Reformers, but certainly on his own responsibility. He knew how to exploit this monopoly to his economic advantage, printing inexpensive hymnbooks in mediocre quality and with minimal adornment. The distribution of large number of songs (over 200) over a short period of time also had an economic aspect, since it allowed buyers to acquire a new hymnal with new songs quickly.

The great Gesangbuch of 1541, an official hymnbook of the Strasbourg church, marks a caesura. The number of songs (only sixty-six) is very limited. Only a few psalms from Köpfel's repertoire were taken over. The names of the authors are given, a practice which Köpfel expressly rejected. Moreover, the target audience and the function of the Gesangbuch differ from the previous hymnbooks. The 'official' Gesangbich was also not printed by Köpfel, but by Georg Messerschmid, who seems to have financed it largely himself.

The situation is different with the hymnbooks of the French exile community. Behind these clearly stood an individual: Jean Calvin, the head of the Strasbourg congregation, and later his successor Pierre Brully. The target group here was not only the few members of the local refugee community, but also foreign French-speaking communities, as is documented in detail in the case of Metz. Katharina Zell's four-part hymnal, containing the repertoire of the Bohemian Brethren, was also an individual initiative, this time private.

So there can be no talk of a targeted guidance on the part of the 'church' until the Interim. At Strasbourg at least, Evangelical songbooks were products of the free market. Of course the preachers influenced the content of the editions, but only indirectly, since it is difficult to sell what is not sung during the church services. The printer also had to reckon with disadvantages if he did not come to terms with the representatives of politics and church. Even with an 'official' hymnbook of the church, like the Gesangbich of 1541, the financing was obviously private, that is, carried by the printer, thus acting simultaneously as publisher.

\section{Appendix}

\section{HDB}

Hymnological Database. Co-operative project between the Johannes Gutenberg-Universität Mainz and Université de Strasbourg, directed by Beat Föllmi and Ansgar Franz. https:/ /hdb.univoak.eu

\section{Meyer}

Meyer, Christian. Les mélodies des Églises protestantes de langue allemande. Catalogue descriptif des sources et édition critique des mélodies: Les mélodies publiées à Strasbourg (1524-1547). Collection d'études musicologiques: 74. Baden-Baden and Bouxwiller: Valentin Koerner, 1987.

\section{Pidoux}

Pidoux, Pierre. Le psautier huguenot du XVI siècle. Mélodies et documents recueillis. 2 vols: I. Les mélodies. II. Documents et bibliographie. Basel: Bärenreiter, 1962. 


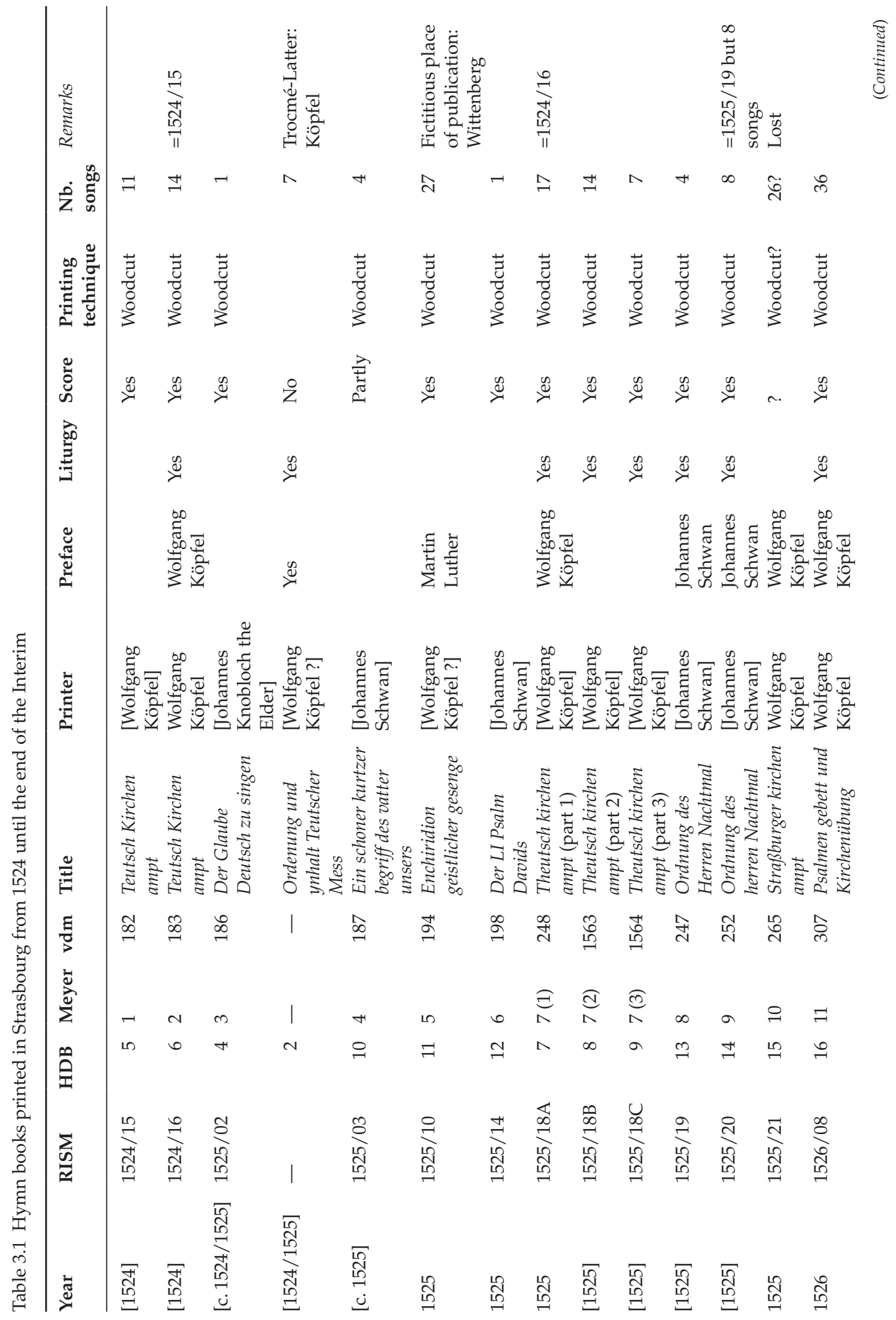




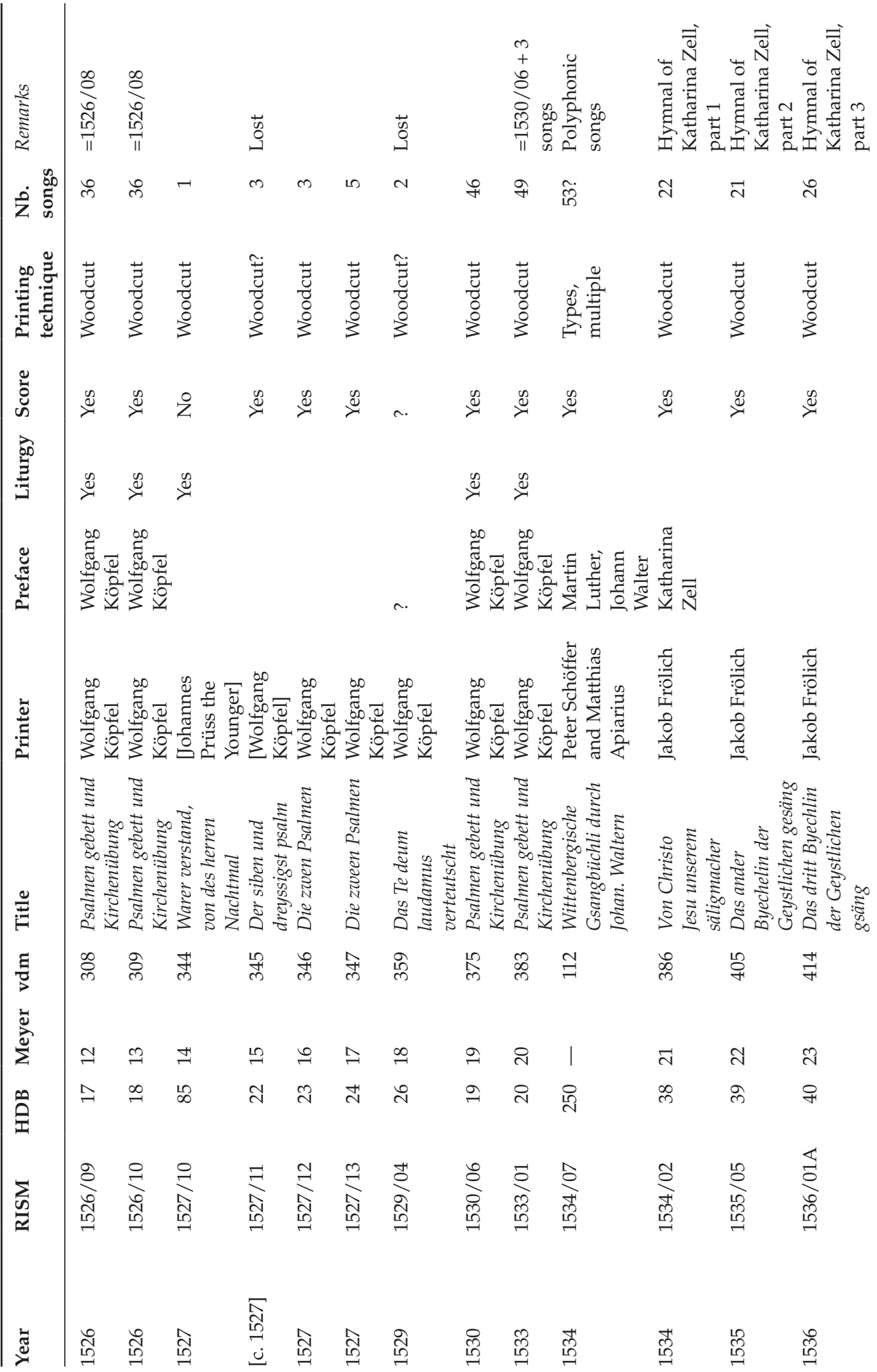




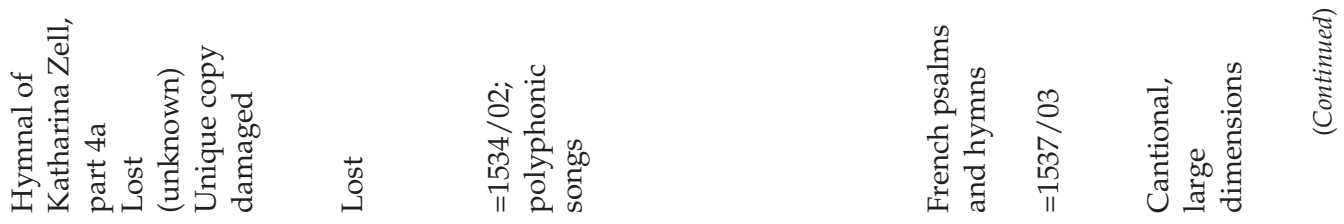

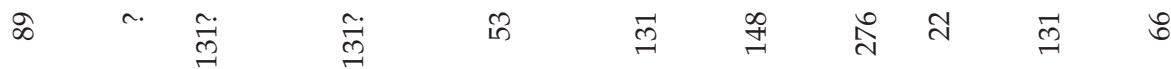

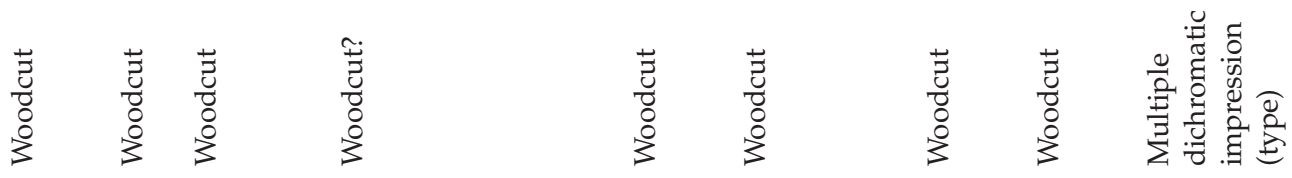

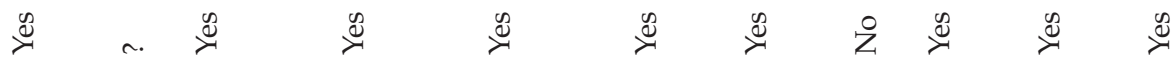

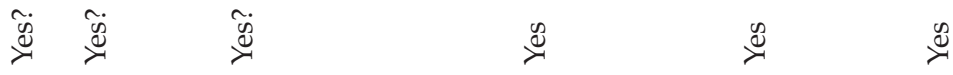

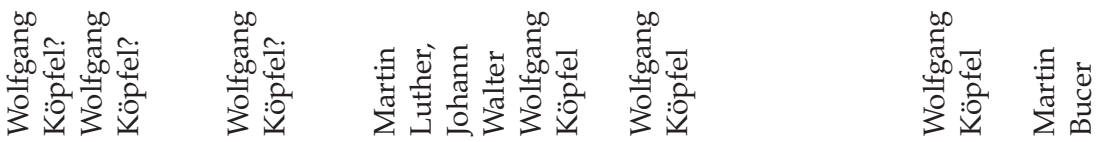

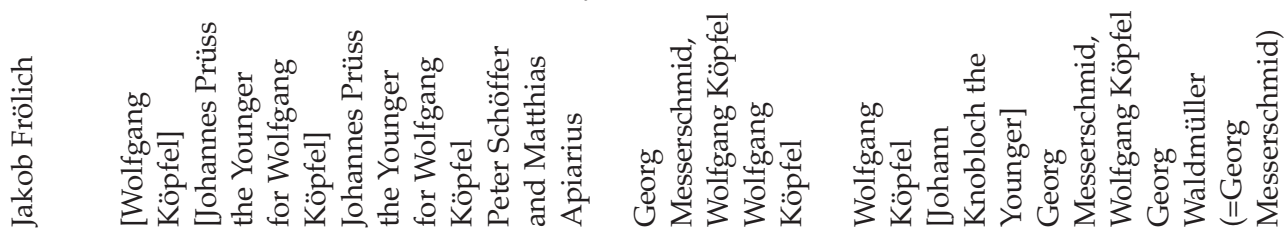

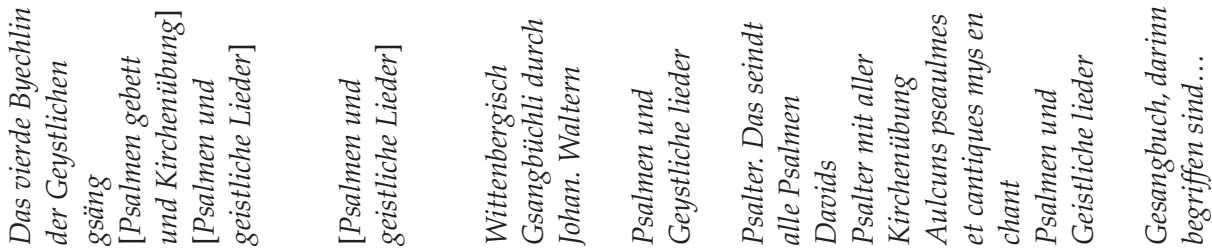

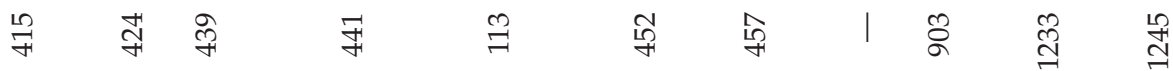

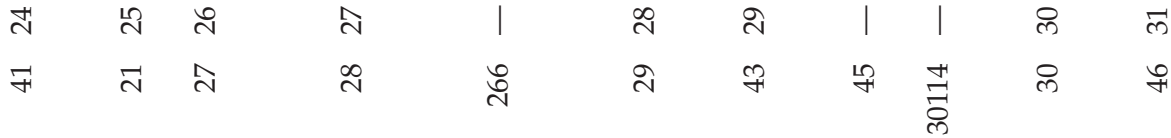

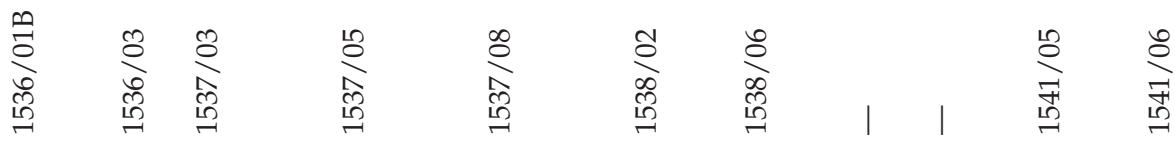

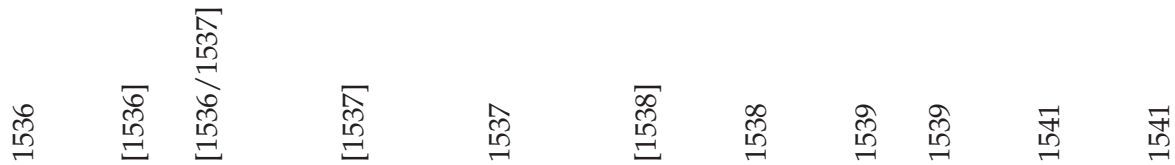




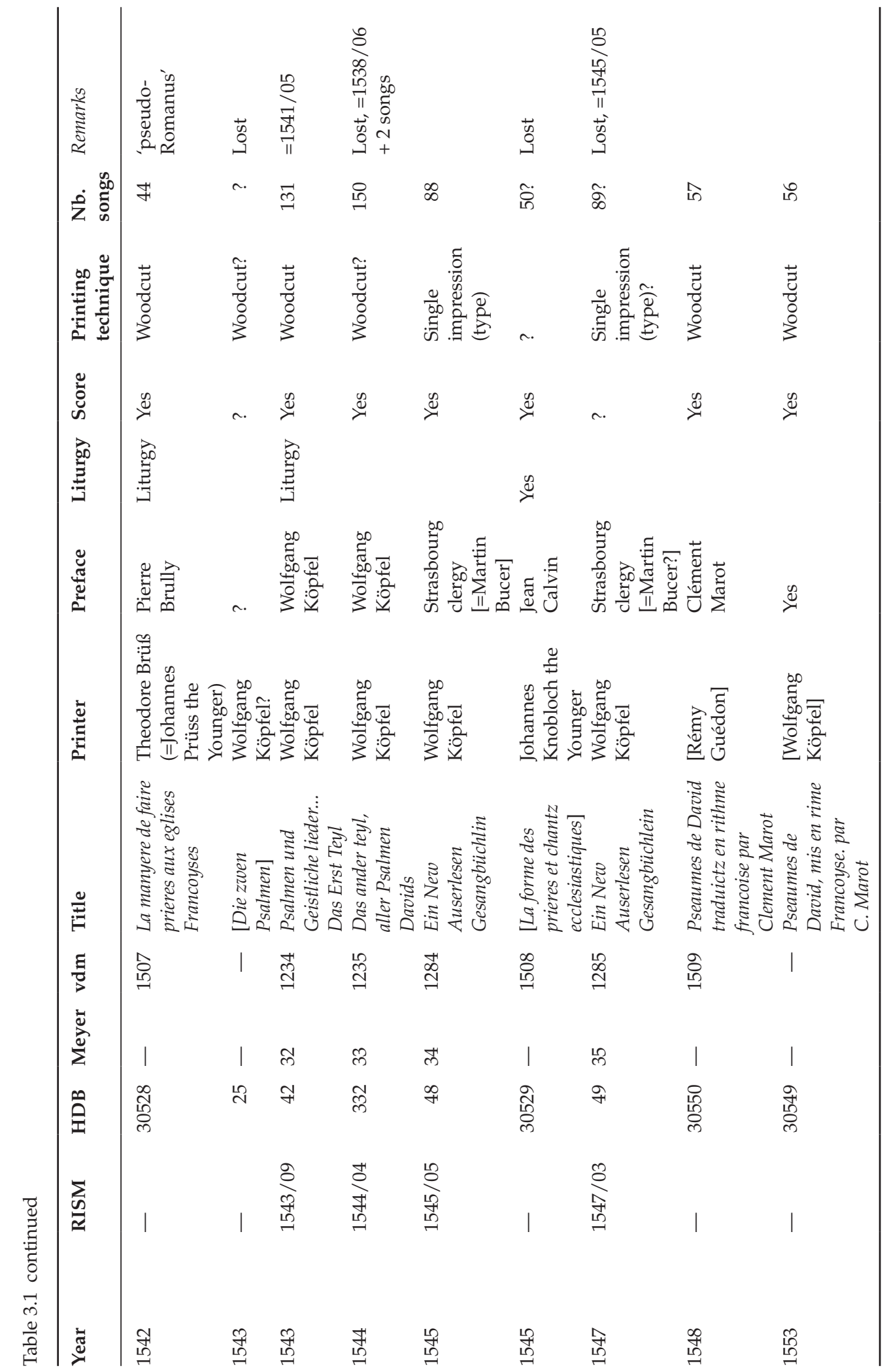




\section{Notes}

1 Pidoux GE 43, HDB 30557; Pidoux GE 53, HDB 30558.

2 Trocmé-Latter, The Singing of the Strasbourg Protestants, 57. This refers to the liturgical orders printed in 1524 and 1525 by Wolfgang Köpfel and others, either with or without melodies. TrocméLatter, however, implicitly assumes that this was an abuse motivated by greed for profit. (See Martin Bucer's letter to Huldrych Zwingli of 1524, published in Bucer, Correspondence, 281, no. 81.) It also leaves open the question of what happened once the 'official decree' existed. Furthermore, he also assumes that hymnbooks were usually commissioned by the churches.

3 Grund und Ursach auss gotlicher Schrifft der Neüwerungen an dem Nachtmal des Herren, so man die Mess nennet, Tauff, Feyrtagen, Bildern und Gesang in der Gemein Christi, wan die zusamen kompt, durch unnd auff das Wort Gottes, zuo Strassburg fürgenomen (Strasbourg: Wolfgang Köpfel, 1525); published in Bucer, Deutsche Schriften, 1: 310-344.

4 The Strasbourg sources and their content were catalogued for the first time by Meyer, Les mélodies des Églises protestantes de langue allemande.

5 The Interim (or Augsburg Interim) was a decree ordered by Charles V on the Diet of Augsburg (May 1548) after the defeat of the Protestant League in the Schmalkaldic War. The decree restored Catholicism but allowed also some Protestant practices. The Interim decree was revoked in 1552.

6 RISM DKL 1557/08, HDB 50. An extended list of all Strasbourg hymnbooks is given in Table 3.1 in the appendix.

7 Der Glaube Deutsch zu singen, RISM DKL 1525/02, HDB 4, vdm 186.

8 Der.li. Psalm Dauids, RISM DKL 1525/14, HDB 12, vdm 198.

9 Warer verstand, von des herren Nachtmal, RISM DKL 1527/10, HDB 85, vdm 344.

10 Das Te deum laudamus verteütscht, RISM DKL 1529/04, HDB 26, vdm 359.

11 Der siben and dreyssigst psalm, RISM DKL 1527/11, HDB 22, vdm 345, with Ps 37 and two Cantica; Die zwen Psalmen, RISM DKL 1527/12, HDB 23, vdm 346, with Ps 114, Ps 139 and the Song of Simeon (Nunc dimittis); The two Psalms, RISM DKL 1527/13, HDB 24, vdm 347, with Ps 114, Ps 115, Ps 139 and two songs by Paul Speratus and Martin Luther.

12 See also Föllmi, 'The Strasbourg Psalter'.

13 Psalmen und geystliche Lieder, RISM DKL 1537/03, HDB 27, vdm 439, for the smaller edition and RISM DKL 1537/05, HDB 28, vdm 441, for the larger edition.

14 Psalmen ond Geystliche lieder, RISM DKL 1538/02, HDB 29, vdm 452.

15 Psalmen ond Geistliche lieder, RISM DKL 1541/05, HDB 30, vdm 1233.

16 Psalmen und Geistliche lieder, RISM DKL 1543/09, HDB 42, vdm 1234.

17 RISM DKL 1538/06, HDB 43, vdm 457.

18 Der ander teyl aller Psalmen Dauids, RISM DKL 1544/04, HDB 332, vdm 1235.

19 Gesangbuich, darinn begriffen sind, die aller fürnemisten ond besten Psalmen/ Geistliche Lieder/ ond Chorgeseng/aus dem Wittembergischen/Strasburgischen/ ond anderer Kirchen Gesangbüchlin zůsamen bracht, RISM DKL 1541/06, HDB 46, vdm 1245.

20 RISM DKL 1545/05, HDB 48, vdm 1248, and RISM DKL 1547/03, HDB 49, vdm 1285; there are no copies of the 1547 edition.

21 First published in 1569, RISM DKL 1569/16, HDB 36.

22 The first part was published in 1534 under the title Von Christo Jesu vnserem säligmacher, RISM DKL 1534/02, HDB 38, vdm 386, the following parts, published in 1535 and 1536, are only called Byechlin der Geystlichen gsäng, RISM DKL 1535/05, HDB 39, vdm 405; RISM DKL 1536/01 (for parts 3 and 4), HDB 40, vdm 414, and HDB 41, vdm 415.

23 RISM DKL 1534/02, HDB 38, vdm 386. The preface of 1534 is printed in Wackernagel, Bibliographie.

24 Aulcuns pseaulmes et cantiques mys en chant, HDB 30114, vdm 903. Facsimile edition with commentary and transmission of the melodies by Terry, 'Calvin's First Psalter, 1539'.

25 For general information on Peter Schöffer see Ritter, Histoire, 317-320; Benzing, 'Peter Schöffer der Jüngere', 133-135, and Lindmayr-Brandl, 'Peter Schöffer der Jüngere', 283-312.

26 RISM DKL 1536/08, vdm 27. A critical reissue of the original can be found in Moser, 65 Deutsche Lieder.

27 Wittenbergische Gsangbüchli, RISM DKL 1534/07, HDB 250, vdm 112, and 1537/08, HDB 266, vdm 113.

28 Rott, 'Note sur l'imprimerie alsacienne', 71.

29 See also Chrisman, 'L'édition protestante à Strasbourg 1519-1560', 221. 
30 Der Glaube Deutsch zu singen, RISM DKL 1525/02, HDB 85, vdm 186.

31 Warer verstand, von des herren Nachtmal, RISM DKL 1527/10, HDB 85, vdm 344.

32 RISM DKL 1525/19, HDB 13, vdm 247; RISM DKL 1525/20, HDB 14, vdm 252.

33 Psalmen ond geystliche Lieder, die man zu Straßburg, vnd auch die man inn anderen Kirchen pflegt zu singen, RISM DKL 1537/03, HDB 27, vdm 439, and RISM DKL 1537/05, HDB 28, vdm 441. From the first edition a single defective copy is known (F-Sn); from the second, none at all.

34 RISM DKL 1538/02, HDB 29, vdm 452.

35 On Georg Messerschmid see Ritter, Histoire, 213-215.

36 RISM DKL 1541/06, HDB 46, vdm 1245.

37 Johannes Ficker suspected that due to the high costs the entire planned volume of songs could not be printed and that the resulting incompleteness of the print had led to neither publishers nor printers being named. In my opinion, this argumentation is unlikely in view of the enormously representative character of the hymnal. Ficker, 'Prachtwerk', 217.

38 Preface, fol. A3v:

[...] der Ersam buchtrucker Jorrg Waldmuller, genant Messerschmid, zů gůt den lieben Kirchen, vnd das gotselig gesang inn den Christlichen Versamlungen, Schůlen vnd Lerheusern zů fưrderen, nicht mit geringem kosten vnd much [hat] sich lassen erbetten vnd bestellen, ein Gesangbůch zůtrucken, auch allen fleis anzůwenden, wie es das werck selb zeuget, das die Psalmen vnd geistliche Lieder, so hierin begriffen, auffs seuberlichest, vnd zům besten corrigieret ausgiengen.

Also printed in Ficker, 'Prachtwerk', 228f.

39 See also Ritter, Histoire, 217.

40 HDB 30114, vdm 903.

41 HDB 30528, vdm 1507; for the fictitious location of printing, see below.

42 HDB 30529, vdm 1508.

43 HDB 30550, vdm 1509.

44 HDB 30549.

45 Enchiridion geistlicher gesenge, 1525, RISM DKL 1525/10, HDB 11, vdm 194; Wittenbergisch Gsangbüchli durch Johan. Waltern, 1534, RISM DKL 1534/07, HDB 250, vdm 112, and 1537, RISM DKL 1537/08, HDB 266, vdm 113.

46 RISM DKL 1524/15, HDB 5, vdm 182.

47 RISM DKL 1524/16, HDB 6, vdm 183.

48 'Vorred', fol. A Iv; printed by Hubert, Ordnungen, 139.

49 RISM DKL 1530/06, HBD 19, vdm 375, fol. Br; preface printed by Hubert, Ordnungen, 141-143.

50 Psalter. Das seindt alle Psalmen Davids, 1538, RISM DKL 1538/06, HDB 43, vdm 457; preface printed by Hubert, Ordnungen, 144. The preface of the first part, RISM DKL 1537/03, HDB 27, vdm 439, published in 1537, is not known because the only known copy (F-Sn) is incomplete.

51 Fol. IIv:

LJeber leser/ Bitzhiehar hab ich die Psalmen/ vnd Geistlichen Lieder wie man die inn den Christlichen gemeinden hien vnd wider pflegt zů singen stucks weiß/ Wie ich die selben zů yeder zeyt hab mo̊gen bekummen/ getruckt/ Nach dem aber/ ietz neülich der gantz Psalter/ mit hỏchstem fleiß/ eigendtlich zů Teutsch gsang Psalmen/ durch vil berümpter fürbindiger II Dichter vnd Poeten/ bitz ans ende volnbracht ist worden. So hab ich mit sampt den vorigen Kirchen ủbungen/ vnd Geistlichen liedern hie zůsamen inn ein Büchlin getruckt $[\ldots]$.

52 RISM DKL 1525/19, HDB 13, vdm 247.

53 Fol. A Iv; printed by Hubert, Ordnungen, 139-140.

54 Fol. A IIv.

55 RISM DKL 1541/06, HDB 46, vdm 1245.

56 Ein New Auserlesen Gesangbüchlin, RISM DKL 1545/05, HDB 48, vdm 1284, and 1547/03, HDB 49, $\mathrm{vdm} 1285$.

57 La forme des prieres et chantz ecclesiastiques (Geneva: Jean Girard, 1542), Pidoux GE 42, HDB 30555.

58 La forme des prieres et chantz ecclesiastiques (Strasbourg: Johann Knobloch the Younger, 1545); Pidoux, ST 45, HDB 30529, vdm 1508.

59 RISM DKL 1526/08, HDB 16, vdm 307, or RISM DKL 1530/06, HDB 19, vdm 375. For examples of the gradual degradation of woodcuts over time, see Ham's chapter in this book. 
60 Pidoux ST 39, HDB 30114, vdm 903.

61 Pidoux ST 45, HDB 30529, vdm 1508, a reprint of the fifty Psalms of Marot published in Geneva in 1542 under the same title, Pidoux GE 42, HDB 30555.

62 Pidoux ST 48, HDB 30550, vdm 1509.

63 Pidoux ST 53, HDB 30549. The name of the printer is not given, but the printer's mark is that of Köpfel.

64 RISM DKL 1534/07, HDB 250, vdm 112, and RISM DKL 1537/08, HDB 266, vdm 113.

65 RISM DKL 1545/05, HDB 48, vdm 1284; RISM DKL 1547/03, HDB 49, vdm 1285 (this edition is lost).

66 RISM DKL 1525/10, HDB 11, vdm 194.

67 RISM DKL 1526/08, HDB 16, vdm 307; RISM DKL 1526/09, HDB 17, vdm 308; RISM DKL 1526/10, HDB 18, vdm 309; RISM DKL 1530/06, HDB 19, vdm 375; RISM DKL 1533/01, HDB 20, vdm 383. The 1536 issue is missing, RISM DKL 1536/03, HDB 21, vdm 427.

68 RISM DKL 1525/02, HDB 4, vdm 186.

69 So it is in RISM DKL 1524/15, HDB 5, vdm 182.

70 RISM DKL 1524/16, HDB 6, vdm 183.

71 See also Fournier, Gymnase.

72 RISM DKL 1545/05, HDB 48, vdm 1284.

73 Such a copy for the Evangelical parish of Effringen (today part of the town of Wildberg in the Black Forest) was made around 1553. Held by the Landeskirchliche Zentralbibliothek, Stuttgart: A13 1553/H31. See also Föllmi, 'Musik und Gesang', 140.

74 Printed by Pidoux, Psautier huguenot, 2: 13.

75 Ibid., 10.

76 Ibid., 11.

77 Ordonnance of 13 October 1543, reprinted in Pidoux, Psautier huguenot, 2: 22.

78 Straßburger kirchen ampt, RISM DKL 1525/21, HDB 15, vdm 265, Foreword: 'die gemein begirig was sollichs zů lesen'. Printed by Hubert, Ordnungen, 140-141.

79 Straßburger kirchen ampt, RISM DKL 1525/21, HDB 15, vdm 265. Printed by Hubert, Ordnungen, 141.

\section{References}

Benzing, Josef. ‘Peter Schöffer der Jüngere. Musikdrucker zu Mainz, Worms, Straßburg und Venedig (tätig 1512-1542)'. Jahrbuch für Liturgik und Hymnologie 4 (1958/59): 133-135.

Bucer, Martin: Correspondance, edited by Jean Rott. Martini Buceri Opera Omnia 3; Studies in Medieval and Reformation Thought, Studies in Medieval and Reformation Traditions. Leiden: Brill, 1979.

Bucer, Martin: Deutsche Schriften. Vol. 1: Frühschriften 1520-1524, edited by Robert Stupperich. Martini Buceri Opera Omnia 1. Gütersloh: Gütersloher Verlagshaus Gerd Mohn; Paris: Presses Universitaires de France, 1960.

Chrisman, Miriam U. 'L'édition protestante à Strasbourg 1519-1560'. In La Réforme et le livre. L'Europe de l'imprimé (1517-v. 1570), edited by Jean-François Gilmont. Cerf-Histoire. Paris: Les Éditions du Cerf, 1990, 217-238.

Ficker, Johannes. 'Das größte Prachtwerk des Straßburger Buchdrucks. Zur Geschichte und Gestaltung des großen Straßburger Gesangbuches 1541'. Archiv für Reformationsgeschichte 38 (1941): 198-230.

Föllmi, Beat. 'Musik und Gesang in der reformatorischen Bewegung'. In Der Sturmwind der Reformation. Luther 1517. Ausstellungskatalog, edited by Madeleine Zeller and Christian Herrmann. Strasbourg: Bibliothèque nationale et universitaire de Strasbourg, 2017, 115-143. [French Edition: Le vent de la Réforme. Luther 1517, edited by Madeleine Zeller and Benoît Jordan. Strasbourg: Bibliothèque nationale et universitaire de Strasbourg, 2017, 115-143].

Föllmi, Beat. 'The Strasbourg Psalter (1537/38): A “Missing Link” for European Hymnology?' In Music and Theology in the European Reformations, edited by David J. Burn, Grantley McDonald, Joseph Verheyden, and Peter De Mey. Epitome Musical. Turnhout: Brepols, 2019, 429-445. 
Fournier, Marcel and Charles Engel. Gymnase, Académie, Université de Strasbourg. Première Partie: 15251621. Les statuts et privilèges des Universités françaises, $2^{\mathrm{e}}$ partie, t. IV, fasc. 1. Paris and Strasbourg: L. Larose and Éditions d'Oleire, 1894.

Hubert, Friedrich. Die Straßburger liturgischen Ordnungen im Zeitalter der Reformation, nebst einer Bibliographie der Straßburger Gesangbücher. Göttingen: Vandenhoeck \& Ruprecht, 1900.

Lindmayr-Brandl, Andrea. 'Peter Schöffer der Jüngere, das Erbe Gutenbergs und "die wahre Art des Druckens"'. In NiveauNischeNimbus: die Anfänge des Musikdrucks nördlich der Alpen, edited by Birgit Lodes. Wiener Forum für ältere Musikgeschichte 3. Tutzing: Hans Schneider, 2010, 283-312.

Meyer, Christian. Les mélodies des Églises protestantes de langue allemande. Catalogue descriptif des sources et édition critique des mélodies: Les mélodies publiées à Strasbourg (1524-1547). Collection d'études musicologiques: 74. Baden-Baden and Bouxwiller: Valentin Koerner, 1987.

Moser, Hans Joachim, ed. 65 Deutsche Lieder für vier- bis fünfstimmigen gemischten Chor a cappella nach dem Liederbuch von Peter Schöffer und Mathias Apiarius (Biener) (Straßburg spätestens 1536). Wiesbaden: Breitkopf \& Härtel, 1967.

Pidoux, Pierre. Le psautier huguenot du XVIe siècle. Mélodies et documents recueillis. 2 vols: I. Les mélodies. II. Documents et bibliographie. Basel: Bärenreiter, 1962.

Ritter, François. Histoire de l'imprimerie alsacienne aux XVe et XVI e siècles. Publications de l'Institut des Hautes Études alsaciennes XIV. Strasbourg and Paris: F.-X. Le Roux, 1955.

Rott, Jean. 'Note sur l'imprimerie alsacienne aux XVe et XVIe siècles'. Revue d'Alsace 95 (1956): 65-76.

Terry, Richard R. 'Calvin's First Psalter, 1539'. Proceedings of the Musical Association. 57th Session (193132). London: Royal Musical Association, 1932, 1-21.

Trocmé-Latter, Daniel. The Singing of the Strasbourg Protestants, 1523-1541. St Andrews Studies in Reformation History. Surrey: Ashgate, 2015.

Wackernagel, Philipp. Bibliographie zur Geschichte des deutschen Kirchenliedes im XVI. Jahrhundert. Frankfurt am Main: Heyder \& Zimmer, 1855 [Reprint: Hildesheim: Olms, 1987]. 